\title{
Determination of in vitro antidiabetic effects of Zingiber officinale Roscoe
}

\author{
Naila Abdul Sattar, Fatma Hussain*, Tahira Iqbal, Munir Ahmad Sheikh
}

Department of Chemistry and Biochemistry, Faculty of Sciences, University of Agriculture, Faisalabad-Pakistan

\begin{abstract}
Aqueous extracts of Zingiber officinale rhizomes were studied to evaluate their antidiabetic effects on protein glycation and on the diffusion of glucose in vitro in the present study. Zingiber officinale rhizome aqueous extract were examined at concentrations of 5, 10, 20 and $40 \mathrm{~g} / \mathrm{L}$. The antidiabetic effects were found to be dose-dependent. Antidiabetic potential of Zingiber officinale was mainly through inhibition of the glucose diffusion and to a limited extent by reducing the glycation. However, further studies are needed to determine in vitro effects of therapeutic potential by restraining postprandial glucose absorptions and plasma protein glycations in diabetic subjects.
\end{abstract}

Uniterms: Zingiber officinale/pharmacognosy. Zingiber officinale/antidiabetic effects/in vitro study. Diabetes mellitus. Hyperglycemia. Proteins/glycation. Glucose/diffusion in vitro.

\begin{abstract}
Extratos aquosos de rizomas Zingiber officinale foram estudados para avaliar os seus efeitos antidiabéticos em glicação de proteínas e sobre a difusão de glicose in vitro, no presente estudo. Extratos aquosos de Zingiber officinale foram examinados nas concentrações de 5, 10,20 e $40 \mathrm{~g}$ extrato de planta/L. Os efeitos antidiabéticos observados eram dependentes da dose. O potencial antidiabético de Zingiber officinale se verificou, principalmente, através da inibição da difusão de glicose e, em menor extensão, através da redução da glicação. Estudos adicionais são necessários para elucidar se efeitos in vitro representam potencial terapêutico, restringindo a absorção de glicose pós-prandial e a glicação de proteínas plasmáticas em indivíduos diabéticos.
\end{abstract}

Unitermos: Zingiber officinale/farmacognosia. Zingiber officinale/efeitos antidiabéticos/estudo in vitro. Diabetes mellitus. Hiperglicemia. Proteinas/glicação. Glicose/difusão in vitro.

\section{INTRODUCTION}

Incubation of proteins with glucose leads to non-enzymatic glycation and formation of amadori products known as an early glycation product. Non-enzymatic glycation of proteins or Maillard reaction is increased in diabetes mellitus due to hyperglycemia and leads to several complications such as blindness, hepatic and cardiovascular diseases, nerve damage and kidney failure (Hussain et al., 2008, 2011; Chen et al., 2011). Normal glucose homeostasis involves glucose absorption via the gut, production by the liver and utilization by nearly all tissues in the body (Kahn, 1992). Diabetes mellitus (DM), a metabolic disorder caused by insufficient or inefficient

\footnotetext{
*Correspondence: F. Hussain. Department of Chemistry and Biochemistry, Faculty of Sciences, University of Agriculture, Faisalabad - Pakistan. E-mail: fatmauaf@yahoo.com
}

insulin secretary response is characterized by hyperglycemia.

Recently, much attention has been focused on natural and synthetic glycation inhibitors to delay the onset or progression of diabetic complications (Rahman et al., 2009; Peng et al., 2011). The scope for the discovery and development of new anti-diabetic therapies from nature's pharmacy is vast and merits corresponding consideration.

Diet has always been recognized as a corner stone in the management of diabetes mellitus. Spices are known to exert several antidiabetic influences (Srinivasan, 2005). Given the large number of plants reputed to possess antidiabetic properties (Saraswat et al., 2010; Ugwuja et al., 2010; Jafri et al., 2011), only a few have received equitable scientific and medical scrutiny in terms of their antiglycation activities. Another often ignored mechanism of anti-diabetic phytomedicines is the role of viscous polysaccharides that control blood glucose concentration by inhibiting intestinal 
glucose absorption (Hagander et al., 1984; Edwards et al., 1988; Groop et al., 1993; Gallagher et al., 2003).

Zingiber officinale (ginger) rhizome is one of the classic examples of an herb used for not only culinary preparations but also for unique therapeutic significance owing to its antioxidant, antimicrobial, anti-inflammatory and chemoprotective potential (Afzal et al., 2001; El-Ghorab et al., 2010; Ghasemzadeh et al., 2010; Rani et al., 2011; Al-Suhaimi et al., 2011; Baliga et al., 2011; Butt, Sultan, 2011; Rehman et al., 2011). Although several studies have mentioned antidiabetic activity of Zingiber officinale (Grover et al., 2002; Akhani et al., 2005; Kelble, 2005; Al-Amin et al., 2006; Büyükbalci, Sedef, 2008; Islam, Choi, 2008; Abd-Elraheem et al., 2009; Saraswat et al., 2009; Ogbera et al., 2010; Saraswat et al., 2010; Madkor et al., 2011; Ramudu et al., 2011; Rani et al., 2011), no data is available on protein glycation and glucose absorption inhibitory potential of native Zingiber officinale rhizomes at national level. The present study was undertaken to investigate the antidiabetic effects of Zingiber officinale in terms of glucose diffusion and glycation inhibition.

\section{MATERIAL AND METHODS}

\section{Extract preparation}

Zingiber officinale rhizomes were collected from Botanical garden, University of Agriculture, Faisalabad, Pakistan during March, 2011. The collected rhizomes were homogenized to fine powder and were stored at room temperature. Aqueous extracts of roots were prepared by cold infusion. One gram powdered material was infused for $15 \mathrm{~min}$ in $40 \mathrm{~mL}$ of boiling distilled water and then filtered, dried under vacuum and stored at $-20^{\circ} \mathrm{C}$ till further analysis. Antidiabetic activity of Zingiber officinale was determined by two methods:

\section{Glycation inhibition}

To study the effect of Zingiber officinale on protein glycation process, fifteen combinations of $0.075 \mathrm{M}$ phosphate buffer saline (PBS) with glucose $\left(\mathrm{G}_{1}: 5.5, \mathrm{G}_{2}: 25\right.$, $\left.\mathrm{G}_{3}: 50 \mathrm{mM}\right)$, Z. officinale $\left(\mathrm{I}_{1}: 5, \mathrm{I}_{2}: 10, \mathrm{I}_{3}: 20, \mathrm{I}_{4}: 40 \mathrm{~g} / \mathrm{L}\right.$ as inhibitor) and protein (bovine albumin) were incubated at $37^{\circ} \mathrm{C}$ for five weeks (Table I). Samples were analyzed after $3^{\text {rd }}$ and $5^{\text {th }}$ weeks of incubation. Glucose concentrations were measured and samples were dialyzed to remove free glucose. Free glucose is the major hindrance in estimation of glycation level. Post-dialysis, glucose was again estimated to confirm final glucose levels. Total proteins in all samples after dialysis were determined by biuret method (Gornall et al., 1949). Thiobarbituric Acid (TBA) colorimetric test was used for the determination of both enzymatic glycation (EG) and non-enzymatic glycation (NEG) as described by Furth (1988).

TABLE I - Different combinations used for glycation inhibition study

\begin{tabular}{llll}
\hline Sr.\# & Combinations & Sr.\# & Combinations \\
\hline 1 & $\mathrm{P}+\mathrm{G}_{1}$ & 9 & $\mathrm{I}_{2}+\mathrm{P}+\mathrm{G}_{3}$ \\
2 & $\mathrm{P}+\mathrm{G}_{2}$ & 10 & $\mathrm{I}_{3}+\mathrm{P}+\mathrm{G}_{1}$ \\
3 & $\mathrm{P}+\mathrm{G}_{3}$ & 11 & $\mathrm{I}_{3}+\mathrm{P}+\mathrm{G}_{2}$ \\
4 & $\mathrm{I}_{1}+\mathrm{P}+\mathrm{G}_{1}$ & 12 & $\mathrm{I}_{3}+\mathrm{P}+\mathrm{G}_{3}$ \\
5 & $\mathrm{I}_{1}+\mathrm{P}+\mathrm{G}_{2}$ & 13 & $\mathrm{I}_{4}+\mathrm{P}+\mathrm{G}_{1}$ \\
6 & $\mathrm{I}_{1}+\mathrm{P}+\mathrm{G}_{3}$ & 14 & $\mathrm{I}_{4}+\mathrm{P}+\mathrm{G}_{2}$ \\
7 & $\mathrm{I}_{2}+\mathrm{P}+\mathrm{G}_{1}$ & 15 & $\mathrm{I}_{4}+\mathrm{P}+\mathrm{G}_{3}$ \\
8 & $\mathrm{I}_{2}+\mathrm{P}+\mathrm{G}_{2}$ & & \\
\hline
\end{tabular}

P: Protein (Bovine albumin), G: Glucose, I: Inhibitor (Zingiber officinale), $\mathrm{G}_{1}: 5.5 \mathrm{mM}, \mathrm{G}_{2}: 25 \mathrm{mM}, \mathrm{G}_{3}: 50 \mathrm{mM} ; \mathrm{I}_{1}: 5 \mathrm{~g} / \mathrm{L}$, $\mathrm{I}_{2}: 10 \mathrm{~g} / \mathrm{L}, \mathrm{I}_{3}: 20 \mathrm{~g} / \mathrm{L}, \mathrm{I}_{4}: 40 \mathrm{~g} / \mathrm{L}$

\section{Non-enzymatic and enzymatic glycation (collective)}

One $\mathrm{mL}$ of dialyzed sample (total protein $=$ $10 \mathrm{mg} / \mathrm{mL}$ ) was used for non-enzymatic and enzymatic glycation. Three test tubes were arranged for each of reduced and non-reduced samples. $0.1 \mathrm{~mL}$ of $\mathrm{NaBH}_{4}$ was added in reduced samples and $0.1 \mathrm{~mL}$ of $0.01 \mathrm{~N} \mathrm{NaOH}$ was added to non-reduced samples. All test tubes were left for 30 minutes at $37^{\circ} \mathrm{C}$. After half an hour, 1 drop of $1 \mathrm{~N} \mathrm{HCl}$ was added in each test tube, followed by addition of $0.5 \mathrm{~mL}$ oxalic acid. Tubes were capped and autoclaved for half an hour at $124{ }^{\circ} \mathrm{C}\left(115 \mathrm{Lb} /\right.$ inch $^{2}$ pressure). Tubes were cooled to room temperature and then placed in ice. In each tube, $0.5 \mathrm{~mL}$ of $40 \%$ trichloroacetic acid (chilled) was added. Afterwards, samples were centrifuged for 15 minutes at $15000 \mathrm{rpm}$. Supernatant $(1.5 \mathrm{~mL})$ was mixed with $0.5 \mathrm{~mL}$ freshly prepared TBA. Later on, the samples were incubated at $37^{\circ} \mathrm{C}$ in water bath for 15 minutes and absorbance was determined at $443 \mathrm{~nm}$.

\section{Enzymatic glycation}

For determination of enzymatic glycation (EG), $0.1 \mathrm{~mL} \mathrm{NaOH}(0.01 \mathrm{~N})$ containing 400 molar excess of $\mathrm{NaBH}_{4}$ was used. After the reduction, the glycation level was determined by the same process as mentioned above. Non-enzymatic glycation(NEG) was determined as follows:

$$
\mathrm{NEG}=(\mathrm{NEG}+\mathrm{EG})-\mathrm{EG}
$$




\section{Glucose diffusion inhibition}

The potential of ginger rhizome extracts to inhibit glucose diffusion into the external solution was investigated at set time intervals (Gallagher et al., 2003). In a dialysis tube $(6 \mathrm{~cm} \times 15 \mathrm{~mm}), 15 \mathrm{~mL}$ of a solution of glucose and $\mathrm{NaCl}(0.15 \mathrm{M})$ was introduced and the appearance of glucose in the external solution was measured. The sealed tube was placed in a centrifuge tube containing $45 \mathrm{~mL}$ of $0.15 \mathrm{M} \mathrm{NaCl}$. The tube was placed on an orbital shaker at room temperature. Glucose concentrations were measured by glucose oxidase kit method. Incremental areas under the glucose curves (AUC) were calculated by trapezoidal rule.

\section{Statistical analysis}

All data were expressed as mean \pm SD and \% age \pm SD of triplicate measurements. Student's t-test was performed by Statistical Package for the Social Sciences (SPSS Inc. Chicago, IL, USA) software (version 15.0) with level of significance set at $p<0.05$.

\section{RESULTS}

Results of antiglycation potential of Zingiber officinale are presented in Figure 1.

For controls, $50 \mathrm{mM}\left(\mathrm{G}_{3}\right)$ glucose exhibited maximum glycation (3.97 mol glucose/mol protein) after five weeks. $\mathrm{G}_{1}(5.5 \mathrm{mM})$ and $\mathrm{G}_{2}(25 \mathrm{mM})$ also showed optimal glycations (3.64 and $3.72 \mathrm{~mol}$ glucose/mol protein). Aqueous extract of $5 \mathrm{~g} / \mathrm{L}$ ginger $\left(\mathrm{I}_{1}\right)$ reduced glycation levels for $\mathrm{G}_{1}(5.5 \mathrm{mM}), \mathrm{G}_{2}(25 \mathrm{mM})$ and $\mathrm{G}_{3}(50 \mathrm{mM})$ as compared to controls and glycation concentrations after $5^{\text {th }}$ week were $3.52,3.48$ and $3.44 \mathrm{~mol}$ glucose $/ \mathrm{mol}$ protein, respectively. Likewise, aqueous extract of $10 \mathrm{~g} / \mathrm{L}\left(\mathrm{I}_{2}\right)$ ginger lowered glycation levels for $\mathrm{G}_{1}, \mathrm{G}_{2}$ and $\mathrm{G}_{3}$ up to $3.33,3.28,3.19$ $\mathrm{mol}$ glucose/mol protein, respectively in the final week. Doubling the extract concentrations $\left(\mathrm{I}_{3}\right)$ as compared to $I_{2}$ further decreased glycation levels (for $G_{1}: 3.01, G_{2}$ : $2.97, \mathrm{G}_{3}: 2.84 \mathrm{~mol}$ glucose $/ \mathrm{mol}$ protein). Percentage differences in glycation of various combinations from controls reduced significantly. Glycation reduction by $\mathrm{I}_{1}$ was not significant for any combination after $3^{\text {rd }}$ or $5^{\text {th }}$ week analysis. $I_{2}$ showed significant decrease with $G_{3}$ in 5 th week. Optimum inhibitor concentrations $\left(\mathrm{I}_{3}\right.$ and $\left.\mathrm{I}_{4}\right)$ indicated significant decline in glycation measurements after $5^{\text {th }}$ week. Most striking observation was maximum glycation inhibition by $\mathrm{I}_{4}$ (Table II).

A simple model was used to investigate glucose absorption inhibition by Zingiber officinale. After $30 \mathrm{~h}$, in the control (without plant extract) glucose movement out of dialysis reached a peak level and glucose concentration in the external solution was $21.20 \mathrm{mmol} / \mathrm{L}$. Different concentrations of $Z$. officinale extracts were used to investigate the dose-dependent effects on glucose diffusion. The plant extracts exhibited a concentration-dependent inhibitory effect on glucose movement (Figure 2).

The effect of variable inhibitor concentrations on

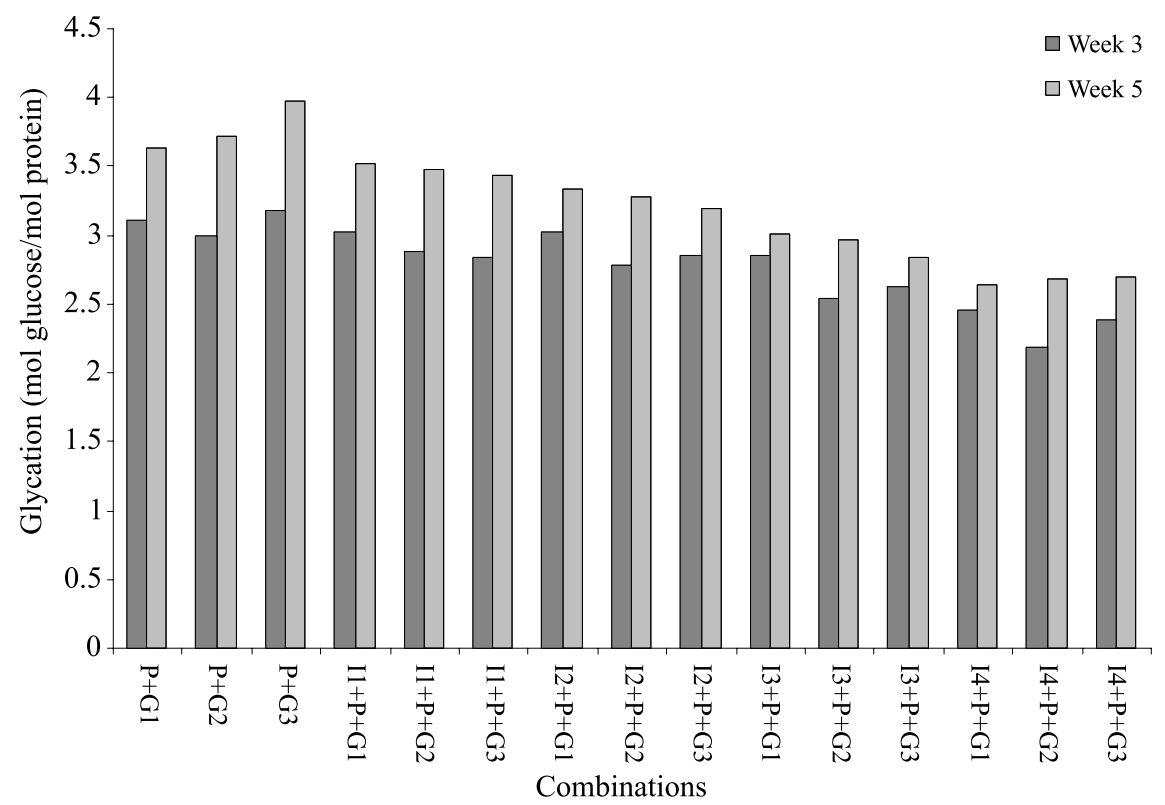

FIGURE 1 - Effect of aqueous extracts of Z. officinale rhizome on glycation levels. Data are mean \pm SD for triplicate measurements. P: Protein (Bovine albumin), G: Glucose, I: Inhibitor (Zingiber officinale), $\mathrm{G}_{1}: 5.5 \mathrm{mM}, \mathrm{G}_{2}: 25 \mathrm{mM}, \mathrm{G}_{3}: 50 \mathrm{mM} ; \mathrm{I}_{1}: 5 \mathrm{~g} / \mathrm{L}, \mathrm{I}_{2}: 10$ $\mathrm{g} / \mathrm{L}, \mathrm{I}_{3}: 20 \mathrm{~g} / \mathrm{L}, \mathrm{I}_{4}: 40 \mathrm{~g} / \mathrm{L}$ 
TABLE II- Percent decrease in glycation levels at different concentrations of plant extracts

\begin{tabular}{lcc}
\hline Combination & $\begin{array}{c}\text { \% Decrease in } \\
\text { glycation after 3 } \\
\text { weeks }\end{array}$ & $\begin{array}{c}\text { \% Decrease in } \\
\text { glycation after 5 } \\
\text { weeks }\end{array}$ \\
\hline Control (no extract) & & - \\
$\mathrm{G}_{1}$ & - & - \\
$\mathrm{G}_{2}$ & - & - \\
$\mathrm{G}_{3}$ & - & $3.30 \pm 0.06$ \\
Plant extract $\left(\mathrm{I}_{1}\right)$ & $2.89 \pm 0.08$ & $-45 \pm 0.02$ \\
$\mathrm{G}_{1}$ & $3.68 \pm 0.18$ & \\
$\mathrm{G}_{2}$ & $10.69 \pm 0.05$ & $13.35 \pm 0.03$ \\
$\mathrm{G}_{3}$ & & \\
${\text { Plant extract }\left(\mathrm{I}_{2}\right)}_{\mathrm{G}_{1}}$ & $2.57 \pm 0.03$ & $8.52 \pm 0.02$ \\
$\mathrm{G}_{2}$ & $7.02 \pm 0.06$ & $11.83 \pm 0.01$ \\
$\mathrm{G}_{3}$ & $10.38 \pm 0.01$ & $19.65 \pm 0.02^{*}$ \\
${\text { Plant extract }\left(\mathrm{I}_{3}\right)}$ & & \\
$\mathrm{G}_{1}$ & $8.04 \pm 0.04$ & $17.31 \pm 0.01^{*}$ \\
$\mathrm{G}_{2}$ & $15.5 \pm 0.20$ & $20.16 \pm 0.01^{*}$ \\
$\mathrm{G}_{3}$ & $17.61 \pm 0.01$ & $28.46 \pm 0.03^{*}$ \\
${\text { Plant extract }\left(\mathrm{I}_{4}\right)}$ & & \\
$\mathrm{G}_{1}$ & $21.22 \pm 0.06^{*}$ & $27.47 \pm 0.01^{*}$ \\
$\mathrm{G}_{2}$ & $26.76 \pm 0.03^{*}$ & $27.69 \pm 0.02^{*}$ \\
$\mathrm{G}_{3}$ & $24.84 \pm 0.02^{*}$ & $31.99 \pm 0.01^{*}$ \\
\hline
\end{tabular}

Data are $\%$ age \pm SD for triplicate measurements.

G: Glucose, I: Inhibitor (Zingiber officinale), $\mathrm{G}_{1}: 5.5 \mathrm{mM}, \mathrm{G}_{2}$ : $25 \mathrm{mM}, \mathrm{G}_{3}: 50 \mathrm{mM} ; \mathrm{I}_{1}: 5 \mathrm{~g} / \mathrm{L}, \mathrm{I}_{2}: 10 \mathrm{~g} / \mathrm{L}, \mathrm{I}_{3}: 20 \mathrm{~g} / \mathrm{L}, \mathrm{I}_{4}: 40 \mathrm{~g} / \mathrm{L}$ $* p<0.05$

${ }^{1}$ Percentage decrease in glycation in comparison to control.

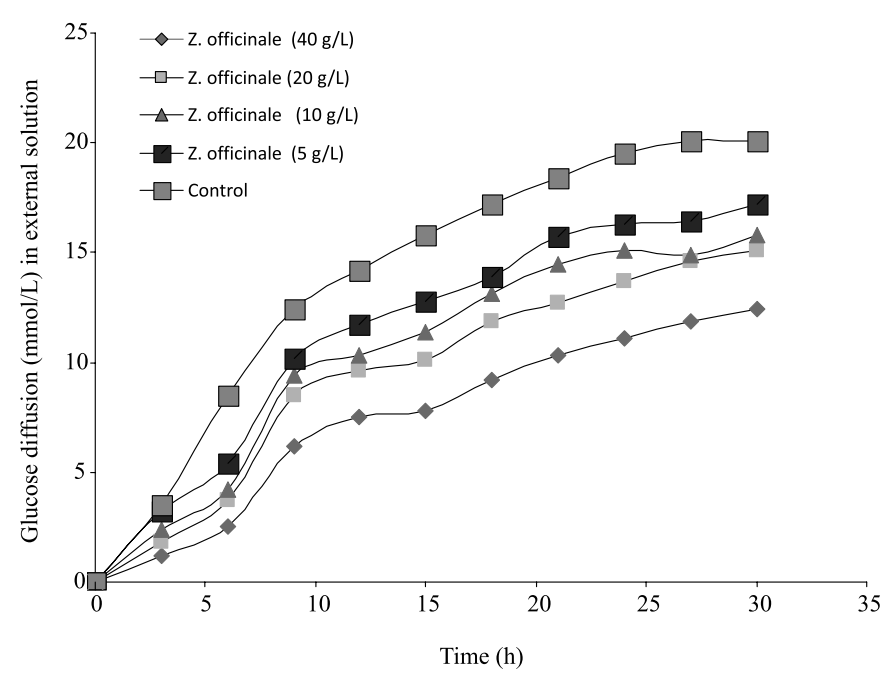

FIGURE 2- Effect of aqueous extracts of $Z$. officinale on glucose diffusion.

glucose diffusion out of the dialysis tube was also assessed in terms of area under curve (AUC) (Table III).

Extract having 20 and $40 \mathrm{~g} / \mathrm{L}$ ginger were the most
TABLE III - Effect of different concentrations of plant extract on glucose diffusion to external solution

\begin{tabular}{lcc}
\hline Sample & $\begin{array}{c}\text { AUC }(\mathrm{mmol} / \mathrm{L} \\
\text { glucose after 30 h) }\end{array}$ & $\begin{array}{c}\text { \% Decrease in } \\
\text { Diffusion }^{2}\end{array}$ \\
\hline Control (no extract) & $416.10 \pm 1.52$ & - \\
Plant extract & & \\
$\mathrm{I}_{4}(40 \mathrm{~g} / \mathrm{L})$ & $221.70 \pm 2.07$ & $46.71 \pm^{*}$ \\
$\mathrm{I}_{3}(20 \mathrm{~g} / \mathrm{L})$ & $282.45 \pm 0.86$ & $32.1 \pm^{*}$ \\
$\mathrm{I}_{2}(10 \mathrm{~g} / \mathrm{L})$ & $309.60 \pm 12.36$ & $25.59 \pm *$ \\
$\mathrm{I}_{1}(5 \mathrm{~g} / \mathrm{L})$ & $342.60 \pm 7.25$ & $17.66 \pm *$ \\
\hline
\end{tabular}

Data are mean \pm SD or $\% \pm$ SD for triplicate measurements. $p<0.05$

${ }^{1}$ AUC: (area under the curve) was calculated using total glucose diffusion during $30 \mathrm{~h}$ incubation period as described in the methods section.

${ }^{2}$ Percentage decrease in movement of glucose into the external solution in comparison to control.

effective inhibitors of glucose movement in the model system. In the presence of $20 \mathrm{~g} / \mathrm{L}$ inhibitor, glucose diffusion was significantly decreased and external glucose concentrations were $15.1 \mathrm{mmol} / \mathrm{L}$ after $30 \mathrm{~h}$. This represents $32.1 \%$ decrease in total glucose diffusion compared to control $(p<0.05)$. Similarly, $40 \mathrm{~g} / \mathrm{L}$ ginger revealed more than $45 \%$ decrease in the glucose movement ( $p<$ 0.05 ) compared to control with a mean external glucose concentration of $12.4 \mathrm{mmol} / \mathrm{L}$ after $30 \mathrm{~h}$. Extracts containing $I_{1}$ and $I_{2}$ inhibitor concentrations were least effective. These extracts demonstrated a mean external glucose concentration of 17.20 and $15.80 \mathrm{mmol} / \mathrm{L}$ after $30 \mathrm{~h}$. The external glucose concentrations after $30 \mathrm{~h}$ were greater at $5 \mathrm{~g} / \mathrm{L}$ compared to $40 \mathrm{~g} / \mathrm{L}$ (17.2 vs $12.4 \mathrm{mmol} / \mathrm{L}$ respectively, $p<0.05)$. Aqueous ginger extracts demonstrated significant inhibitory effects on glucose movement into external solution across dialysis membrane compared to control. For all the test samples, the overall rates of glucose movement into external solution were lower than that of control. The results underline the importance of Zingiber officinale against the diabetic conditions mainly through inhibition of the glucose absorption and to a lesser extent by its antiglycating potential. The therapeutic use of nutrients needs further exploration for the prevention or delay of diabetic complications.

\section{DISCUSSION}

Nonenzymatic glycation of proteins or Maillard reaction is increased in diabetes mellitus due to hyperglycemia (Hussain et al., 2008; Cárdenas-León et al., 2009; Hussain et al., 2010; Hussain et al., 2011; Schalkwijk, Miyata, 2012). Numerous synthetic and natural com- 
pounds with different glycation inhibition mechanisms are reviewed in literature. However, owing to the side effects of synthetic molecules, all future expectations rely on natural antiglycation compounds (Peng et al., 2011).

Ginger can lower the blood glucose, improve activities of mitochondrial enzymes and could be used as a nephro-protective supplement particularly to reverse diabetic complications (Saraswat et al., 2010; Ramudu et al., 2011). The potential effects of Zingiber officinale in terms of protein glycation and glucose diffusion inhibition were evaluated in the present study.

Thiobarbituric colorimetric assay was used to establish the concentration and time dependent inhibition of protein glycation by ginger. Four different concentrations of aqueous extracts of ginger rhizomes were used to determine the time-dependent changes in protein glycation levels after three and five weeks of incubation at $37{ }^{\circ} \mathrm{C}$ in the presence and absence of plant extracts. Ginger extract concentrations of $\mathrm{I}_{3}(20 \mathrm{~g} / \mathrm{L})$ and $\mathrm{I}_{4}(40 \mathrm{~g} / \mathrm{L})$ showed significant percent reduction $(28.46 \pm 0.03-31.99 \pm 0.01)$ in NEG. Hence the extracts showed a dose-dependent inhibition of protein glycation. Previously, $63 \%$ glycation inhibition by ginger at the concentration of $1.0 \mathrm{mg} / \mathrm{mL}$ was reported (Saraswat et al., 2009).

Reduction in glycation can be justified by the fact that non-enzymatic glycation is the covalent binding of reducing sugars to $\alpha$ - or $\varepsilon$ - amino groups on protein. This glycation lowering activity can be linked to the presence of various phenolic components in ginger rhizomes. The pungent fractions of ginger, namely gingerols, shogaols, paradols, and volatile constituents like sesquiterpenes and monoterpenes, are mainly attributed to the healthenhancing perspectives of ginger (Al-Amin et al., 2006; Ojewole, 2006; Islam, Choi, 2008; Butt, Sultan, 2011). The NEG inhibitory activity of ginger depends, at least in part, on its ability to trap reactive carbonyl intermediates in NEG/AGE formation, thereby inhibiting the chemical modification of proteins. In terms of preventing protein and sugar cross-links, the aqueous extracts of ginger showed 30-80\% reductions (Saraswat et al., 2009).

The above-mentioned inferences confirm the ability of $Z$. officinale extracts to lower the protein glycation in an empirical in vitro manner by TBA assay. Other chemical methods and in vivo models might not be able to produce similar reductions in protein glycation process by these extracts.

Incubation period also affected glycation process. The percentage inhibitions in NEG after third week became significant when incubations were prolonged to five weeks indicating decline in potential glycation with time. In recent years, much interest has been focused on the role of viscous polysaccharides in the treatment of diabetes mellitus. The action of the polysaccharides in reducing postprandial hyperglycemia is thought to be related to their viscosity. Viscous polysaccharides may delay glucose absorption probably by impairing the access of luminal contents to the absorptive epithelium (Hagander et al., 1984; Edwards et al., 1988; Groop et al., 1993).

Ginger extracts also prevented or reduced glucose movement and evaluated percent decrease predicted the action of the plant polysaccharides on hyperglycemia in vivo. High concentration extracts $(20,40 \mathrm{~g} / \mathrm{L})$ showed greater percent decrease $(32 \%-46.7 \%)$ in glucose movement. The results suggested that the part of the antihyperglycemic actions of ginger may be by decreasing glucose absorption in vivo. The main mechanism concerning the role of dietary fiber in lowering postprandial serum glucose is the viscosity of different dietary fibers in hampering diffusion of glucose and postponing absorption and digestion of carbohydrates as these bind glucose and resultantly decrease the concentration of available glucose in the small intestine (Ou et al., 2001). Gallagher et al. (2003) studied the ability of different plants to inhibit glucose diffusion. They reported that agrimony and avocado represented the greatest inhibitory effect on glucose diffusion (more than 60\%). Mushrooms, coriander, eucalyptus, juniper, lucerne and mistletoe decreased significantly (ranged 6\%-48\%). While elder and nettle extracts did not significantly decrease glucose diffusion. Contrary to these findings, Büyükbalci and Sedef (2008) observed that the overall rates of glucose movement into external solution were higher than control for ten aqueous herbal tea extracts. None of the samples demonstrated significant inhibitory effects on glucose movement into external solution across dialysis membrane compared to the control. Further studies are required to elucidate in vitro effects regarding postprandial glucose absorptions and for improving glycemic control in diabetic subjects.

In conclusion, results of the present study suggest that $Z$. officinale rhizomes with antiglycating and antidiabetic/hypoglycemic properties might provide a viable approach, either food based or pharmacological, in the treatment of diabetic complications.

\section{REFERENCES}

ABD-ELRAHEEM, A.E.; SALMAN, M.M.A.; MOUSSA, M.M.A. Effect of ginger extract consumption on levels of blood glucose, lipid profile and kidney functions in alloxan induced diabetic rats. Egypt. Acad. J. Biolog. Sci., v.2, n.1, p.153-162, 2009. 
AFZAL, M.; AL-HADIDI, D.; MENON, M.; PESEK, J.; DHAMI, M.S. Ginger: an ethnomedical, chemical and pharmacological review. Drug Metab. Drug Interact., v.18, n.3/4, p.159-190, 2001.

AKHANI, S.P.; VISHAWAKARMA, S.L.; GOYAL, R.K. Antidiabetic activity of Zingiber officinale roscoe in streptozotocin -induced non-insulin dependent diabetic rats. Indian J. Pharm. Sci., v.67, n.5, p.553-557, 2005.

AL-AMIN, Z.M.; THOMSON, M.; AL-QATTAN, K.K.; PELTONEN-SHALABY, R.; ALI, M. Anti-diabetic and hypolipidaemic properties of ginger (Zingiber officinale) in streptozotocin-induced diabetic rats. Br. J. Nutr., v.96, n.4, p.660-666, 2006

AL-SUHAIMI, E.A.; AL-RIZIZA, N.A.; AL-ESSA, R.A. Physiological and therapeutical roles of ginger and turmeric on endocrine functions. Am. J. Chinese. Med., v.39, n.2, p.215-231, 2011.

BALIGA, M.S.; HANIADKA, R.; PEREIRA, M.M.; D’SOUZA, J.J.; PALLATY, P.L.; BHAT, H.P.; POPURI, $\mathrm{S}$. Update on the chemopreventive effects of ginger and its phytochemicals. Crit. Rev. Food Sci. Nutr., v.51, n.6, p.499-523, 2011.

BUTT, M.S.; SULTAN, M.T. Ginger and its health claims: molecular aspects. Crit. Rev. Food Sci. Nutr., v.51, n.5, p.383-393, 2011.

BÜYÜKBALCI, A.; SEDEF N.E. Determination of in vitro antidiabetic effects, antioxidant activities and phenol contents of some herbal teas. Plant Foods Hum. Nutr., v.63, n.1, p.27-33, 2008.

CÁRDENAS-LEÓN, M.; DÍAZ-DÍAZ, E.; ARGÜELLESMEDINA, R.; SÁNCHEZ-CANALES, P.; DÍAZSÁNCHEZ, V.; LARREA, F. Glycation and protein crosslinking in the diabetes and ageing pathogenesis. Rev. Invest. Clin., v.61, n.6, p.505-520, 2009.

CHEN, L.; MAGLIANO, D.J.; ZIMMET, P.Z. The worldwide epidemiology of type 2 diabetes mellitus-present and future perspectives. Nat. Rev. Endocrinol., v.8, n.4, p.228-236, 2011.

EDWARDS, C.A.; JOHNSON, I.T.; READ, N.W. Do viscous polysaccharides slow absorption by inhibiting diffusion or convection? Eur. J. Clin. Nutr., v.42, n.4, p.307-312, 1988.
EL-GHORAB, A.H.; NAUMAN, M.; ANJUM, F.M.; HUSSAIN, S.; NADEEM, M.A Comparative study on chemical composition and antioxidant activity of ginger (Zingiber officinale) and cumin (Cuminum cyminum). J. Agric. Food Chem., v.58, n.14, p.8231-8237, 2010.

FURTH, A.J. Methods for assaying non-enzymatic glycosylation; a review. Anal. Biochem., v.175, n.2, p.347-360, 1988.

GALLAGHER, A.M.; FLATT, P.R.; DUFFY, G.; ABDELWAHAB, Y.H.A. The effects of traditional antidiabetic plants on in vitro glucose diffusion. Nutr. Res., v.23, n.3, p.413-424, 2003.

GHASEMZADEH, A.; JAAFAR, H.Z.E.; RAHMAT, A. Antioxidant activities, total phenolics and flavonoids content in two varieties of Malaysian young ginger (Zingiber officinale Roscoe). Molecules, v.15, n.6, p.43244333, 2010.

GORNALL, A.G.; BARDAWILL, C.J.; DAVID, M.M. Determination of serum proteins by means of biuret reaction. J. Biol. Chem., v.177, n.2, p.751-766, 1949.

GROOP, P.H.; ARO, A.; STENMAN, S.; GROOP, L. Long-term effects of guar gum in subjects with non-insulin dependent diabetes mellitus. Am. J. Clin. Nutr., v.58, n.4, p.513-518, 1993.

GROVER, J.K.; YADAV, S.; VATS, V. Medicinal plants of India with anti-diabetic potential. J. Ethnopharmacol., v.81, n.1, p.81-100, 2002.

HAGANDER, B.; SCHERSTEN, B.; ASP, N.G.; SARTOR, G.; AGARDH, C.D.; SCHREZENMEIR, J.; KASPER, H.; AHREN, B.; LUNDQUIST, I. Effect of dietary fibre on blood glucose, plasma immunoreactive insulin, C-peptide and GIP responses in non-insulin-dependent (type 2) diabetics and controls. Acta Med. Scand., v.215, n.3, p.205$213,1984$.

HUSSAIN, F.; SHEIKH, M.A.; ARIF, M.; ARSHAD, A.; JAMIL, A. Non-enzymatic glycation in diabetic complications. Saudi. Med. J., v.29, n.2, p.303-304, 2008.

HUSSAIN, F.; SHEIKH, M.A.; JAMIL, A.; NAWAZ, H. Advanced glycation end-products and foot ulceration in type 2 diabetic patients: a case control study. Int. J. Agric. Biol., v.12, n.1, p.91-95, 2010. 
HUSSAIN, F.; ARIF, M.; SHEIKH, M.A. Prevalence of diabetic retinopathy in Faisalabad, Pakistan: A population based study. Turk. J. Med. Sci., v.41, n.4, p.735-742, 2011.

ISLAM, M.S.; CHOI, H. Comparative effects of dietary ginger (Zingiber officinale) and garlic (Allium sativum) investigated in a type 2 diabetes model of rats. J. Med. Food, v.11, n.1, p.152-159, 2008.

JAFRI, S.A.; ABASS, S.; QASIM, M. Hypoglycemic effect of ginger (Zingiber officinale) in alloxan induced diabetic rats (Rattus norvegicus). Pak. Vet. J., v.31, n.2, p.160-162, 2011.

KAHN, B.B. Facilitative Glucose Transporters: Regulatory mechanisms and dysregulation in Diabetes. J. Clin. Invest., v.89, n.5, p.1367-1374, 1992.

KELBLE, A. Spices and type 2 diabetes. Nutr. Food Sci., v.35, n.2, p.81-87, 2005.

MADKOR, H.R.; MANSOUR, S.W.; RAMADAN, G. Modulatory effects of garlic, ginger, turmeric and their mixture on hyperglycaemia, dyslipidaemia and oxidative stress in streptozotocin-nicotinamide diabetic rats. Br. J. Nutr., v.105, n.8, p.1210-1217, 2011.

OGBERA, A.O.; DADA, O.; ADELEYE, F.; JEWO, P.I. Complementary and alternative medicine use in diabetes mellitus. West Afr. J. Med., v.29, n.3, p.158-162, 2010.

OJEWOLE, J.A. Analgesic. antiinflammatory and hypoglycaemic effects of ethanol extract of Zingiber officinale (Roscoe) rhizomes (Zingiberaceae) in mice and rats. Phytother. Res., v.20, n.9, p.764-772, 2006.

OU, S.; KIN-CHOR, K.; YAN, L.; LIANG, F.U. In vitro study of possible role of dietary fiber in lowering postprandial serum glucose. J. Agric. Food Chem., v.49, n.2, p.10261029, 2001.

PENG, X.; MA, J.; CHEN, F.; WANG, M. Naturally occurring inhibitors against the formation of advanced glycation endproducts. Food Funct., v.2, n.6, p.289-301, 2011.

RAHMAN, S.; ISMAIL, A.A.; RAHMAN, A.R. Treatment of diabetic vasculopathy with rosiglitazone and ramipril: hype or hope? Int. J. Diabetes Dev. Ctries., v.29, n.3, p.110-117, 2009.
RAMUDU, S.K.; KORIVI, M.; KESIREDDY, N.; LEE, L.C.; CHENG, I-S.; KUO, C-H.; KESIREDDY, S.R. Nephroprotective effects of a ginger extract on cytosolic and mitochondrial enzymes against streptozotocin (STZ)induced diabetic complications in rats. Chinese J. Physiol., v.54, n.2, p.79-86, 2011.

RANI, M.P.; PADMAKUMARI, K.P.; SANKARIKUTTY, B.; CHERIAN, O.L.; NISHA, V.M.; RAGHU, K.G. Inhibitory potential of ginger extracts against enzymes linked to type 2 diabetes, inflammation and induced oxidative stress. Int. J. Food Sci. Nutr., v.62, n.2, p.106-110, 2011.

REHMAN, R.; AKRAM, M.; AKHTAR, N.; JABEEN, Q.; SAEED, T.; SHAH, S.M.A.; AHMED, K.; SHAHEEN, G.; ASIF, H.M. Zingiber officinale Roscoe (pharmacological activity). J. Med. Plant Res., v.5, n.3, p.344-348, 2011.

SARASWAT, M.; REDDY, P.Y.; MUTHENNA, P.; REDDY, G.B. Prevention of non-enzymic glycation of proteins by dietary agents: prospects for alleviating diabetic complications. Br. J. Nutr., v.101, n.11, p.1714-1721, 2009.

SARASWAT, M.; SURYANARAYANA, P.; REDDY, P.Y.; PATIL, M.A.; BALAKRISHNA, N.; REDDY, G.B. Antiglycating potential of Zingiber officinalis and delay of diabetic cataract in rats. Mol. Vis., v.16, n.165-166, p.1525$1537,2010$.

SCHALKWIJK, C.G.; MIYATA, T. Early- and advanced nonenzymatic glycation in diabetic vascular complications: the search for therapeutics. Amino Acids, v.42, n.4, p.11931204, 2012.

SRINIVASAN, K. Plant foods in the management of diabetes mellitus: spices as beneficial antidiabetic food adjuncts. Int. J. Food Sci. Nutr., v.56, n.6, p.399-414, 2005.

UGWUJA, E.I.; NWIBO, A.N.; UGWU, N.C.; ALOKE, C. Effects of aqueous extract of spices mixture containing curry, garlic and ginger on plasma glucose and lipids in alloxan-induced diabetic rats. Pak. J. Nutr., v.9, n.12, p.1131-1135, 2010 .

Received for publication on $30^{\text {th }}$ January 2012 Accepted for publication on $18^{\text {th }}$ June 2012 